\title{
Pengenalan Abjad pada Anak Usia Dini Melalui Media Kartu Huruf
}

\author{
Ratna Pangastuti dan Siti Farida Hanum \\ UIN Sunan Ampel Surabaya \\ Email: ratnapangastuti@hotmail.com
}

\begin{abstract}
This study aims to examine factors that affect a child's ability to recognize letters of the alphabet and distinguish several letters that have similar sounds and shape. By using alphabetical card (flashcard) researchers want to improve the ability of objects in recognizing and distinguish letters. This research uses a qualitative descriptive approach with case study research in action research design. Data collection techniques through observation, interviews, and documentation. Semi-structured interview used by researchers to obtain the completeness of the data and find out the problem in detail. The results obtained that the development of the alphabetical is increasing because of stimulus with a alphabetical card. With a child's card game it becomes more fun to recognize the alphabets and can directly play with the alphabetical card directly. In addition to recognizing the alphabets, with a child's alphabetical card can also explore his knowledge through the pictures, colors and shapes that existed in the letters. It indicates that subject has achieved good results in recognizing the alphabet, since from the beginning he has not been able to distinguish the present letters than subject can distinguish letters of similar shape. In addition, subject also able to know the initial letter of a word and can read it.
\end{abstract}

Keywords: Alphabetical Introduction, Alphabetical Card 


\section{PENDAHULUAN}

Kemampuan bahasa anak sangat berkaitan erat dengan kemampuan kognisinya. Lev Vygotsky mengemukakan bahwa bahasa memiliki kedudukan penting dalam perkembangan kognitif anak. Bahasa merupakan alat mental yang berfungsi sebagai mekanisme aktual untuk berfikir. Dengan bahasa maka pemikiran lebih abstrak dan luwes. Melalui bahasa juga, ingatan dan antisipasi ke masa depan dibawa ke situasi baru. Bahasa juga dapat membuat anak-anak lebih imajinatif, mengubah (manipulasi), menciptakan gagasan-gagasan baru dan membagi gagasan-gagasan itu dengan anak lain (Yuliana Nurani Sujiono, dkk., 2014: 4-10).

Ditemukan dalam penelitian ini, ada dua faktor sebagai penyebab anak kesulitan mengingat abjad, yaitu faktor internal dan faktor eksternal. Faktor internal yaitu faktor yang ada pada diri anak tersebut meliputi perkembangan kognitif, motivasi, minat belajar, dan emosi. Faktor eksternal berarti faktor dari luar diri anak yang meliputi lingkungan keluarga, sekolah, dan masyarakat. Dimana ketiga lingkungan ini oleh Ki Hajar Dewantara disebut dengan Tripurusa. Ketika dilingkungan keluarga, ananda $\mathrm{X}$ jarang mendapatkan perhatian dari orang tuanya, dikarenakan ananda $X$ masih memiliki adik yang berusia 3 bulan sehingga perhatian ibu lebih banyak tercurah kepada sang adik sedang ayah sibuk bekerja. Saat dilingkungan sekolah, kemungkinan media yang digunakan oleh guru kurang optimal sehingga tidak menarik dan merangsang minat dan perkembangan anak.

Peran media dalam sebuah pembelajaran merupakan hal yang terpenting karena digunakan sebagai pengantar atau perantara untuk menyampaikan sebuah pembelajaran. Dengan adanya media yang inovatif, dimaksudkan dapat sebagai penghubung agar anak dapat mengingat apa yang telah dipelajarinya dan pembelajarannyapun lebih bermakna. Adapun media yang digunakan dalam riset ini adalah kartu huruf atau flashcard, dengan harapan dapat lebih menarik minat, perhatian dan motivasi ananda X untuk belajar mengenal abjad. Dengan media kartu huruf (flashcard) yang sudah tidak asing dan sangat familiar di masyarakat ini, anak dapat belajar mengenal huruf secara nyata karena tidak hanya mengamati abjad dengan mengoptimalkan otak kirinya saja, namun dengan ilustrasi gambar dan warna menarik yang analog dengan bunyi huruf awal dapat menstimulasi otak kanan anak sehingga informasi 
yang terserap melibatkan kedua belah otak yang akhirnya akan masuk pada long term memory, tidak hanya pada neokorteks.

Fokus permasalahan dari riset ini adalah kemampuan ananda $X$ dalam mengenal abjad, penggunaan media kartu huruf (flashcard) dalam mengenalkan abjad pada ananda X, dan bagaimana kartu huruf (flashcard) dapat meningkatkan kemampuan ananda $X$ dalam mengenal abjad. Riset ini menggunakan pendekatan deskriptif kualitatif dengan jenis riset study kasus mengenai cara meningkatkan daya ingat anak terhadap abjad melalui media kartu huruf. Namun pada penyajian hasil dan pembahasan, peneliti memodifikasi dengan mengkolaborasikannya seperti tahap-tahap pada penelitian tindakan kelas namun disajikan dalam bentuk deskriptif. Teknik pengumpulan data melalui observasi, wawancara, dan dokumentasi. Data dikumpulkan melalui observasi yang dilakukan ketika dirumah dan disekolah ananda X. Wawancara semi terstruktur digunakan peneliti untuk mendapatkan kelengkapan data dan mengetahui permasalahan secara detail. Wawancara ini dilakukan kepada guru kelas. Observasi dan wawancara lebih dilakukan pada aspek bahasa anak khususnya mengenai kemampuan mengenal huruf dan mendokumentasikan proses observasi dalam bentuk foto kegiatan anak. Instrumen riset ini akan peneliti lampiran pada bagian akhir laporan riset ini.

\section{PEMBAHASAN}

Perkembangan kemampan berbahasa anak usia 4-6 tahun ditandai dengan berbagai kemampuan seperti (Mudjito, 2007: 3): (a) mampu menggunakan kata ganti 'saya' dan berkomunikasi, (b) memiliki berbagai perbendaharaan kata kerja, kata sifat, kata keadaan, kata tanya, dan kata sambung, (c) menunjukkan pengertian, dan pemahaman tentang sesuatu, (d) mampu mengungkapkan pikiran, perasaan, dan tindakan dengan menggunakan kalimat sederhana, (e) mampu membaca dan mengungkapkan sesuatu melalui gambar. Tingkat pencapaian perkembangan bahasa anak usia 4-5 tahun dapat melakukan hal-hal sebagai berikut: menerima bahasa, mengungkapkan bahasa, dan keaksaraan. Tingkat pencapaian perkembangan menerima bahasa anak diharapkan dapat: menyimak perkataan orang lain, mengerti dua perintah yang diberikan bersamaan, memahami cerita yang dibacakan, mengenal perbendaharaan kata (Standart Pendidikan Anak Usia 
Dini). Kemampuan mengungkap bahasa meliputi mengulang kalimat sederhana, menjawab pertanyaan sederhana, mengungkapkan perasaan dengan kata sifat, menyebut katakata yang dikenal, mengutarakan pendapat kepada orang lain, menyatakan alasan terhadap sesuatu yang diinginkan atau ketidak setujuan, menceritakan kembali cerita/dongeng yang pernah didengar. Kemampuan keaksaraan anak meliputi mengenal simbol-simbol, mengenal suara-suara hewan/benda yang ada disekitarnya, membuat coretan yang bermakna, dan meniru huruf (Mudjito, 2007: 11). Perkembangan bahasa dapat distimulasi oleh orang terdekat anak, seperti orang tua, guru, pengasuh, saudara dan sebagainya. Berhubung anak belajar bahasa melalui meniru/modeling, maka orang disekitar perlu mengajak bicara, dan dengan bahasa yang benar. Metode pengembangan bahasa yang dapat diterapkan antara lain bercerita, sosiodrama, permainan membaca dan lain-lain (Rita Eka Izzaty dkk., 2008: 91). Perkembangan kemampuan berbahasa pada anak usia dini dengan cara mulai mengenalkan nama dirinya atau nama benda yang ada disekitarnya, akan membantu anak secara cepat dalam mengenal huruf-huruf, kata-kata, dan suara (Harun Rasyid dkk., 2009: 129). Melatih mengenal huruf menjadi bagian penting dalam membangun kemampuan bahasa anak usia dini.

Belajar mengenal huruf merupakan komponen hakiki dari perkembangan baca tulis. Anak perlu mengetahui atau mengenal dan memahami huruf abjad untuk akhirnya menjadi pembaca dan penulis yang mandiri dan lancar. Anak- anak yang bisa mengenal dan menyebut huruf-huruf pada daftar abjad dalam belajar membaca memiliki kesulitan lebih sedikit dari anak yang tidak mengenal huruf (Carol Seefeld dan Barbara A. Wasik, 2008: 330-331). Kemampuan mengenal huruf merupakan tahap perkembangan anak dari belum tahu menjadi tahu tentang keterkaitan bentuk dan bunyi huruf, sehingga anak dapat mengetahui bentuk huruf dan memaknainya (Soenjono Dardjowidjojo, 2003: 300). Mengenal huruf merupakan hal penting bagi anak usia dini yang didengar dari lingkungannya baik huruf latin, huruf Arab dan lainnya. Berbagai huruf yang dikenal anak menumbuhkan kemampuan untuk memilih dan memilah berbagai jenis huruf. Melatih anak untuk mengenal huruf dan mengucapkannya mesti harus diulang-ulang (Harun Rasyid dkk., 2009: 241). Sesuai dengan Peraturan Menteri Pendidikan Nasional Republik Indonesia No 58 Tahun 2009 tentang Standar Pendidikan Anak Usia Dini, kemampuan mengenal huruf merupakan bagian dari perkembangan bahasa 
anak, diantaranya kemampuan mengetahui simbol-simbol huruf dan mengetahui huruf depan dari sebuah benda.

Berdasarkan beberapa pendapat para ahli maka dapat disimpulkan bahwa kemampuan mengenal huruf merupakan tahap perkembangan dimana anak mampu dan mengetahui simbol-simbol dari sebuah huruf. Tingkat keberhasilan dari kemampuan mengenal huruf dapat diukur saat anak dapat memaknai huruf sehingga anak mampu menyebutkan huruf awal dari kata. Belajar huruf adalah tonggak kurikulum Taman Kanak-kanak lewat penyingkapan berulang dan bermakna kepada peristiwa-peristiwa baca tulis, sehingga anak menjadi tahu akan huruf-huruf dan mengerti bahwa huruf-huruf membentuk sebuah kata (Carol Seefeld dan Barbara A. Wasik, 2008: 375). Strategi pengenalan huruf sejak usia dini sangat bermanfaat bagi perkembangan bahasa anak, karena membantu mempersiapkan anak untuk dapat membaca dengan mudah (Agus Hariyanto, 2009: 82). Selain itu anak yang dapat mengenal huruf dengan baik, juga cenderung memiliki kemampuan membaca dengan lebih baik (Slamet Suyanto, 2005: 165). Jadi berdasarkan hal-hal tersebut dapat disimpulkan bahwa manfaat yang didapat anak apabila belajar mengenal huruf sejak usia dini maka dapat mempersiapkan kemampuan anak dalam belajar membaca dan menulis.

Fungsi dari media pembelajaran tersebut adalah sebagai daya tarik sehingga kegiatan belajar mengajar dapat berjalan dengan lebih menarik, siswa lebih bergairah dan termotivasi dalam menjalani proses pembelajaran, serta materi yang disampaikan pun dapat diserap oleh siswa dengan baik. Dalam penelitian ini media berperan penting sebagai daya tarik dalam kegiatan proses belajar mengajar, dan media akan mempermudah dalam memberikan pemahaman kepada anak tentang sesuatu hal. Dengan adanya media maka akan diperoleh hasil optimal, dan pembelajaran akan lebih efektif dan menyenangkan.

Kartu huruf adalah penggunaan sejumlah kartu sebagai alat bantu untuk belajar membaca dengan cara melihat dan mengingat bentuk huruf dan gambar yang disertai tulisan dari makna gambar pada kartu (Maimunah Hasan, 2009: 65). Kartu huruf adalah kartu abjad yang berisi gambar, huruf, tanda simbol, yang meningkatkan atau menuntun anak yang berhubungan dengan simbol-simbol tersebut. Namun demikian kata huruf yang dimaksud disini adalah kartu huruf yang dibuat sendiri dengan bentuk persegi panjang terbuat dari kertas putih. Satu sisi terdapat tempelan potongan huruf dan satu sisinya lagi 
terdapat tempelan gambar benda yang disertai tulisan dari makna gambar tersebut (Azhar Arsyad, 2005: 119).

Jadi berdasarkan penjelasan tersebut dapat ditegaskan bahwa metode kartu huruf adalah suatu kegiatan dengan menggunakan alat atau media berupa kartu huruf yang terdapat simbol huruf dan gambar yang disertai tulisan dari makna gambarnya, dengan tujuan meningkatkan kemampuan mengetahui atau mengenal dan memahami huruf abjad.

Beberapa manfaat yang dapat diambil dari permainan kartu huruf menurut Maimunah Hasan (2009: 65) antara lain:

1. Dapat membaca dengan mudah

2. Permainan kartu huruf dapat membantu anak untuk mengenal huruf dengan mudah, sehingga membantu anakanak dalam kemampuan membacanya.

3. Mengembangkan daya ingat otak kanan

4. Permainan kartu huruf dapat mengembangkan kemampuan otak kanan karena dapat melatih kecerdasan emosi, kreatif, dan intuitif.

5. Memperbanyak perbendaharaan kata. Permainan kartu huruf terdapat gambar dan tulisan dari makna gambar yang tertera pada kartu, sehingga dapat memperbanyak perbendaharaan kata yang dimiliki anak-anak

Fungsi kartu huruf di antaranya yakni untuk mengenalkan huruf pada anak usia 4-6 tahun dengan lebih cepat karena dengan bantuan alat peraga guru dapat menjelaskan lebih banyak hal dalam waktu yang singkat dan mencapai hasil lebih cepat dengan cara yang menyenangkan (Andang Ismail, 2006: 181). 
Tabel 1. Kisi-Kisi Observasi

\begin{tabular}{|c|c|c|c|}
\hline No. & Subjek & Komponen & Indikator \\
\hline 1. & Anak & Kemampuan anak & $\begin{array}{l}\text { - Kemampuan anak ketika belajar dikelas } \\
\text { - Kemampuan anak ketika belajar } \\
\text { mengenal abjad }\end{array}$ \\
\hline \multirow[t]{3}{*}{2.} & \multirow[t]{3}{*}{ Guru kelas } & Kemampuan anak & $\begin{array}{l}\text { - Kemampuan anak pada bidang lain } \\
\text { - } \quad \text { Upaya pendekatan yang dilakukan oleh } \\
\text { guru kelas dalam mengenalkan abjad } \\
\text { kepada anak }\end{array}$ \\
\hline & & $\begin{array}{l}\text { Penggunaan media } \\
\text { dalam mengenalkan } \\
\text { abjad pada anak }\end{array}$ & $\begin{array}{l}\text { - Media yang digunakan guru kelas untuk } \\
\text { mengenalkan abjad pada anak }\end{array}$ \\
\hline & & Upaya guru & $\begin{array}{l}\text { - Variasi pembelajaran yang dilakukan } \\
\text { guru agar kemampuan anak mengingat } \\
\text { dalam mengenal abjad }\end{array}$ \\
\hline
\end{tabular}

Tabel 2. Rubrik observasi

\begin{tabular}{|c|c|c|}
\hline No. & Komponen & Kriteria \\
\hline 1. & Kemampuan anak & $\begin{array}{ll}\text { - } & \text { Kemampuan anak dalam menunjukkan huruf } \\
\text { - } & \text { Kemampuan anak dalam menyebutkan huruf } \\
\text { - } & \text { Kemampuan anak dalam menghubungkan } \\
& \text { gambar dengan huruf } \\
\text { - } & \text { Kemampuan anak pada bidang lain }\end{array}$ \\
\hline 2. & $\begin{array}{l}\text { Penggunaan } \quad \text { media } \\
\text { pembelajaran oleh guru kelas }\end{array}$ & $\begin{array}{l}\text { - Media yang menunjang pembelajaran } \\
\text { - } \quad \text { Hasil penggunaan media yang digunakan }\end{array}$ \\
\hline 3. & Upaya yang dilakukan guru & $\begin{array}{l}\text { - Variasi pembelajaran yang diberikan kepada } \\
\text { anak untuk merangsang kemampuan anak }\end{array}$ \\
\hline
\end{tabular}

Tabel 3. Kisi-kisi wawancara untuk guru kelas

\begin{tabular}{|c|c|c|}
\hline No. & Komponen & Indikator \\
\hline 1. & Kemampuan anak & $\begin{array}{l}\text { - Kemampuan anak mengenal abjad ketika awal di } \\
\text { kelompok B } \\
\text { - Kemampuan anak pada bidang lain }\end{array}$ \\
\hline 2. & Penggunaan media & $\begin{array}{l}\text { - Media penunjang pembelajaran yang digunakan untuk } \\
\text { mengenalkan abjad pada anak }\end{array}$ \\
\hline 3. & $\begin{array}{l}\text { Upaya yang } \\
\text { dilakukan guru }\end{array}$ & $\begin{array}{l}\text { - Inovasi pembelajaran yang dilakukan guru dalam } \\
\text { meningkatkan kemampuan mengenal abjad pada anak }\end{array}$ \\
\hline
\end{tabular}


Tabel 4. Rubrik wawancara untuk guru kelas

\begin{tabular}{|c|c|c|}
\hline No. & Komponen & Kriteria \\
\hline 1. & Kemampuan anak & $\begin{array}{l}\text { - Kemampuan anak dalam mengenal huruf saat berada } \\
\text { diawal TK B } \\
\text { - Kemampuan anak pada bidang lain ketika disekolah } \\
\text { - } \text { Kemampuan anak dalam menunjukkan huruf } \\
\text { - } \text { Kemampuan anak dalam menyebutkan huruf } \\
\text { - Kemampuan anak dalam menghubungkan gambar } \\
\text { dengan huruf } \\
\text { - } \\
\text { Penyebab kemampuan anak dalam mengenal abjad } \\
\text { mengalami keterlambatan }\end{array}$ \\
\hline 2. & $\begin{array}{l}\text { Penggunaan media } \\
\text { pembelajaran }\end{array}$ & $\begin{array}{l}\text { - Media penunjang yang diberikan guru agar kemampuan } \\
\text { anak meningkat }\end{array}$ \\
\hline 3. & $\begin{array}{l}\text { Upaya yang } \\
\text { dilakukan guru }\end{array}$ & $\begin{array}{l}\text { - Upaya yang dilakukan guru dalam meningkatkan } \\
\text { kemampuan anak } \\
\text { - Inovasi pembelajaran yang dilakukan agar kemampuan } \\
\text { anak meningkat }\end{array}$ \\
\hline
\end{tabular}

\section{TEMUAN PENELITIAN}

Berdasarkan hasil observasi dan wawancara diperoleh hasil bahwa kemampuan anak dalam mengenal abjad belum optimal karena saat peneliti meminta subjek untuk menunjukkan suatu abjad tertentu subjek masih kesulitan dan salah saat menunjukkan abjad tertentu. Begitu juga saat menyebutkan huruf dan saat peneliti mendikte suatu kata, subjek masih kesulitan jika harus menulisnya langsung dan penelitipun menunjukkan huruf yang dimaksud dengan cara menuliskan huruf yang dimaksud. Guru kelas subjekpun juga menuturkan demikian, kemampuan subjek dalam mengenal abjad belum maksimal. Ada beberapa huruf yang belum subjek kuasai sehingga saat mendikte dikelas ataupun menyuruh subjek menunjukkan suatu abjad guru harus merangsangnya terlebih dahulu dengan memberi tahu subjek bentuk abjad itu seperti apa, misal huruf $\mathrm{M}$ berarti memiliki tiga kaki dsb.

Jika dalam hal mengenal abjad kemampuan subjek belum terlalu mampu, lain halnya dengan aspek perkembangan lainnya. Perkembangan bahasa dalam hal berkomunikasi sudah lancar, perkembangan sosial subjek juga baik. Berdasarkan penuturan yang disampaikan guru kelas, kemampuan anak dalam bergaul dengan temannya ketika disekolah juga baik. Subjek suka membantu temannya dan suka berbagi. Kemampuan fisik motorik anak juga berkembang dengan baik. 
Menurut penuturan guru kelas penyebab mengapa kemampuan anak dalam mengenal abjad kurang optimal yakni karena daya ingat anak terbatas dan kemungkinan setelah mendapatkan materi disekolah dirumah anak tidak mengulangnya kembali atau bahkan orang tua kurang membiasakan untuk mengajarkan itu kepada anak. Berdasarkan observasi yang saya lakukan memang benar bahwa dirumah subjek kurang mendapatkan pembiasaan dalam hal mengenal abjad. Kalaupun dirumah subjek diajarkan untuk mengenal abjad namun orangtuanya cenderung kurang sabar dalam mendampingi abjad untuk belajar. Kondisi subjek juga sekarang sedang menjadi kakak yang artinya intensitas perhatian orangtua kepada subjek menjadi berkurang.

Guru kelas juga menuturkan bahwa setelah mengetahui kondisi subjek dalam mengenal abjad kurang optimal maka guru kelas menggunakan cara mengajar yang dapat merangsang kemampuan subjek. Salah satu cara yang digunakan yakni dengan memberi perhatian yang lebih intens kepada anak. Salah satunya ketika dicela-cela waktu istirahat guru menyuruh anak untuk membaca tulisan yang tertempel didinding atau tulisan yang ada dibuku. Apabila anak tidak mengerti maka guru memberi tahu anak dengan menyebutkan ciri-ciri dari abjad tersebut. Guru juga memberitahu bahwa sebenarnya disekolah ada juga beberapa anak yang memiliki kemampuan kurang lebih seperti subjek. Berawal dari kondisi subjek kurang optimal dalam hal mengenal abjad maka timbulah keprihatinan pada subjek dan akhirnya peneliti melakukan upaya agar subjek dapat meningkatkan kemampuan mengenal abjad. Cara yang dilakukan peneliti untuk mengenalkan abjad yakni melalui kartu huruf agar anak lebih tertarik dan termotivasi untuk belajar.

\section{Hasil penelitian kemampuan anak setelah dilakukan tindakan}

Hasil dari penelitian akan diurutkan bedasarkan siklus :

1. Tindakan Siklus I

Pada siklus I ini terdiri dari tiga tahapan yakni tahap perencanaan, tindakan dan pengamatan dan yang terakhir refleksi. 


\section{a. Perencanaan}

Pada kegiatan perencanaan ini peneliti merencanakan untuk meningkatkan kemampuan mengenal abjad kepada subjek dengan memerintah subjek mengambil abjad yang ada pada kartu huruf sesuai dengan perintah peneliti dan subjek diminta untuk menunjukkan abjad apa saja dari kata yang telah diucapkan peneliti. Selanjutnya subjek diminta untuk menghubungkan gambar dengan abjad yang ada pada kartu huruf. Tujuannya yakni sebagai langkah awal untuk mengetahui seberapa faham dan mengerti subjek terhadap abjad yang disebutkan peneliti.

b. Tindakan dan pengamatan

1) Tindakan pertemuan pertama siklus I

Pertemuan ini dilaksanakan pada hari Sabtu, 22 April 2017. Pada kegiatan ini ada tiga tahap yakni kegiatan awal, inti dan akhir. Pada kegiatan awal peneliti menjelaskan kepada subjek bagaimana cara memainkan kartu huruf tersebut. Dalam memainkan kartu huruf pada pertemuan pertama siklus I ini diharapkan subjek dapat menunjukkan huruf yang telah disebutkan oleh peneliti. Kemudian pada kegiatan inti subjek diminta untuk menunjukkan abjad yang telah disebut oleh peneliti. Karena masih berada di tahap awal, maka peneliti tetap membimbing dan mengarahkan subjek dalam menunjukkan abjad. Saat subjek belum tahu huruf yang dimaksud maka peneliti membantunya dengan cara menunjukkan ciri-ciri huruf tersebut. Dan tiba pada kegiatan akhir yakni peneliti bertanya kepada subjek bagaimana perasaanya setelah bermain kartu huruf tersebut serta menanyakan apakah mau bermain lagi dengan kartu huruf dan tak lupa peneliti memberi ucapan terimakasih dan motivasi agar tetap semangat dalam belajar.

2) Tindakan pertemuan kedua siklus I

Pertemuan kedua di siklus I ini dilaksanakan pada hari Ahad, 23 April 2017. Seperti pada pertemuan pertama siklus I, dipertemuan kedua siklus I juga ada tiga tahap yakni kegiatan awal, inti dan akhir. Pada kegiatan awal peneliti menanyakan kegiatan yang telah dilkaukan kemarin dan menjelaskan kepada subjek bagaimana cara memainkan kartu huruf tersebut dan nantinya subjek diharap dapat menyebutkan abjad. Pada kegiatan inti dalam memainkan kartu huruf pada pertemuan kedua siklus I ini subjek menyebutkan abjad apa saja dari kata yang peneliti ucapkan. Lalu kegiatan penutup yakni peneliti 
bertanya kepada subjek bagaimana perasaanya setelah bermain kartu huruf tersebut serta menanyakan apakah mau bermain lagi dengan kartu huruf dan tak lupa peneliti memberi ucapan terimakasih dan motivasi agar tetap semangat dalam belajar.

\section{3) Tindakan pertemuan ketiga siklus I}

Pertemuan ketiga ini dilakukan pada hari Senin, 24 April 2017. Seperti kegiatan yang sudah dilakukan pada pertemuan pertama dan kedua bahwa pada kegiatan awal yakni peneliti bertanya kegiatan yang sudah dilakukan kemarin dan menjelaskan kepada subjek bahwa kegiatan hari ini terdiri dari tiga kegiatan yakni menunjukkan huruf, menyebutkan huruf dan menghubungkan gambar dengan huruf. Kegiatan awal yakni peneliti menjelaskan kepada anak bagaimana cara bermain pada kegiatan ini. Kedua yakni kegiatan ini yang berarti subjek menunjukkan huruf yang telah peneliti sebutkan, kegiatan selanjutnya yakni menyebutkan huruf dari kata yang telah diucapkan peneliti dan selanjutnya menghubungkan gambar dengan huruf. Dan pada kegiatan akhir atau penutup peneliti bertanya kepada subjek bagaimana perasaanya setelah bermain kartu huruf tersebut serta menanyakan apakah mau bermain lagi dengan kartu huruf dan tak lupa peneliti memberi ucapan terimakasih dan motivasi agar tetap semangat dalam belajar.

\section{c. Refleksi}

Tahap refleksi pada siklus I ini merupakan proses mengevaluasi hasil tindakan yang telah dilakkan pada siklus I. Hasil dari evaluasi ini akan dijadikan perbaikan pada siklus selanjutnya. Berdasarkan data yang telah diperoleh dari tindakan pada siklus I maka dapat disimpulkan bahwa kemampuan subjek dalam mengenal abjad meningkat, melalui media kartu huruf kemampuan anak dalam mengenal abjad meningkat, meskipun sudah mengalami peningkatan dalam mengenal abjad tetapi peningkatan tersebut belum memenuhi target dan standar.

Berdasarkan kesimpulan ersebut maka peneliti memutuskan untuk melaksanakan kegiatan penelitian kembali dengan melanjutkan pada siklus II dengan harapan hasil yang diperoleh lebih optimal dan mencapain standar perkembangan anak usia subjek. Adapun langkah-langkah perencanaan yang akan dilakukan yakni: (1) Memberikan kegiatan yang lebih bervariasi, dan (2) Memberi motivasi lebih kepada anak baik secara verbal, 
non verbal maupun dengan pemberian reward berupa bunga dari kertas origami.

\section{Tindakan siklus II}

Pada siklus II sama seperti siklus I yakni terdiri dari tiga tahapan pertama tahap perencanaan, tindakan dan pengamatan dan yang terakhir refleksi.

\section{a. Perencanaan}

Pada kegiatan perencanaan ini peneliti merencanakan untuk memberikan variasi dalam meningkatkan kemampuan mengenal abjad kepada subjek. Cara yang digunakan hampir sama dengan siklus I namun ada tambahan yakni dengan memerintah subjek untuk membaca kata yang ada pada kartu huruf dan mendikte sabjek untuk menulis kata yang diucapkan peneliti. Tujuannya yakni mempersiapkan subjek untuk menjadi membaca dan penulis yang mandiri dan lancar.

b. Tindakan dan pengamatan

1) Tindakan pertemuan pertama siklus I

Pertemuan ini dilaksanakan pada hari Senin, 1 Mei 2017. Pada kegiatan ini ada tiga tahap yakni kegiatan awal, inti dan akhir. Pada kegiatan awal peneliti menjelaskan kepada subjek bagaimana cara memainkan kartu huruf tersebut dan menanyakan kegiatan yang telah dilakukan beberapa hari yang lalu. Kemudian kegiatan inti yakni subjek diminta untuk mengambil satu kartu secara acak dan menyebutkan abjad apa saja yang ada di kartu huruf tersebut kemudian menunjukkan abjad dengan ciri-ciri huruf. Di kegiatan akhir peneliti memberi reward berupa bunga dari kertas origamikepada subjek jika berhasil.

\section{2) Tindakan pertemuan kedua siklus II}

Tindakan ini dilaksanakan pada hari selasa, 2 Mei 2017. Seperti tindakan pada pertemuan sebelumnya, kegiatan awal berupa tanya jawab kegiatan yang sudah dilakukan kemarin. Selanjutnya pada kegiatan inti yakni subjek diminta untuk mengambil satu kartu secara acak dan menyebutkan abjad apa saja yang ada di kartu huruf tersebut kemudian menunjukkan abjad dengan ciriciri huruf dan terakhir membaca kata yang tertulis pada kartu huruf. Di kegiatan akhir peneliti memberi reward berupa bunga dari kertas origamikepada subjek jika berhasil.

3) Tindakan pertemuan ketiga siklus II 
Tindakan ini dilaksanakan pada hari Rabu, 3 Mei 2017. Kegiatan awal sama dengan kegiatan sebelumnya yakni menanyakan kegiatan kemarin yang telah dilakukan subjek. Kegiatan inti sama seperti pertemuan pertama dan kedua siklus II hanya saja pada kegiatan akhir subjek di dikte oleh peneliti untuk menulis sebuah kata agar kemampuan dalam mengenal abjad semakin baik. Di kegiatan yang terakhir peneliti memberi motivasi kepada subjek dan memberinya reward berupa bunga dari kertas origamikepada subjek jika berhasil.

\section{c. Refleksi}

Tahap refleksi siklus II merupakan evalusi hasil tindakan yang dilakukan pada siklus II. Berdasarkan data yang diperoleh, maka dapat disimpulkan bahwa kemampuan subjek dalam mengenal abjad mengalami peningkatan lebih baik dari sebelumnya, memenuhi taget dan standar yang diharapkan dan kemampuan mengenal huruf yang distimulasi dengan media kartu huruf dapat membuat anak menjadi lebih senang, aktif dan kreatif.

Mengenal abjad dapat dilakukan dengan berbagai metode, salah satunya yakni dengan menggunakan media kartu huruf. Metode kartu huruf merupakan suatu kegiatan dengan menggunakan alat atau media berupa kartu huruf yang terdapat simbol huruf dan gambar yang disertai tulisan dari makna gambarnya, dengan tujuan meningkatkan kemampuan mengetahui atau mengenal dan memahami huruf abjad. Bermain dengan kartu huruf diawali dengan mengenalkan cara menggunakan kartu huruf tersebut. Melalui kartu huruf ini anak dapat meningkatkan kemampuannya dalam mengenal abjad menjadi lebih asyik dan menyenangkan.

Hasil penelitian yang dilakukan selama 2 siklus yang terdiri dari 6 kali pertemuan tersebut menunjukkan bahwa kemampuan subjek semakin meningkat dari kondisi awal sebelum diadakan penelitian hingga tindakan siklus II sampai pada tahap akhir. Selain itu penggunaan media kartu huruf juga dapat meningkatkan kemampuan subjek dalam mengenal abjad. Karena kartu huruf berfungsi untuk mengenalkan huruf pada anak usia 4-6 tahun dengan lebih cepat karena dengan bantuan alat peraga guru dapat menjelaskan lebih banyak hal dalam waktu yang singkat dan mencapai hasil lebih cepat dengan cara yang menyenangkan (Andang Ismail, 2006: 181).

Berdasarkan teori-teori yang telah dikemukakan, peneliti menyimpulkan bahwa kemampuan mengenal abjad dapat ditingkatkan melalui media kartu kata. Karena melalui media kartu huruf tersebut subjek dapat juga mengenal berbagai 
bentuk, huruf, warna dan kata. Kartu huruf juga sangat efektif saat digunakan dalam pembelajaran karena dapat membantu guru mengoptimalkan materi yang akan disampaikan terutama saat ingin mengenalkan abjad kepada peserta didik. Media pembelajaran tersebut juga lebih efektif dibanding dengan hanya mengenalkan abjad dipapan tulis dan pembelajaran pun tidak monoton dan lebih bermakna karena dapat mengaktifkan pesertaa didik, mengasyikan serta menyenangkan bagi mereka.

\section{SIMPULAN}

Berdasarkan hasil penelitian dan pembahasan dalam penelitian ini dapat disimpulkan bahwa perkembangan mengenal abjad subjek semakin meningkat karena adanya rangsangan atau stimulus dengan kartu huruf. Dengan permainan kartu huruf anak menjadi lebih senang dalam mengenal abjad-abjad dan secara langsung dapat bermain-main langsung dengan kartu huruf. Selain dapat mengenal abjad-abjad, dengan kartu huruf anak juga dapat mengeksplorasi pengetahuannya melalui gambargambar, warna dan bentuk-bentuk yang ada dikartu huruf tersebut.

Hal ini menunjukkan bahwa subjek telah mencapai hasil yang baik dalam mengenal abjad, karena dari yang awalnya belum dapat membedakan huruf sekarang subjek sudah dapat membedakan huruf yang bentuknya hampir sama. Selain itu subjek juga sudah dapat mengetahui huruf awal dari sebuah kata dan dapat membacanya. Dengan begitu sudah memenuhi standar Peraturan Menteri Pendidikan Nasional Republik Indonesia No 58 Tahun 2009 tentang Standar Pendidikan Anak Usia Dini, yakni kemampuan mengenal huruf merupakan bagian dari perkembangan bahasa anak, diantaranya kemampuan mengetahui simbol-simbol huruf dan mengetahui huruf depan dari sebuah benda.

\section{DAFTAR PUSTAKA}

Arsyad, Azhar. 2005. Media Pembelajaran. Jakarta: Raja Grafindo Persada.

Artini, Ni Made Sri dkk. 2013. Penerapan Metode Pemberian Tugas Berbantuan Media Kartu Huruf untuk Meningktakan Kemampuan Mengenal Konsep Huruf pada TK Kelompok 
B Tunas Mulia. Jurnal Universitas Pendidikan Ganesha Singaraja Indonesia.

Dardjowidjojo, Soenjono. 2003. Pengantar Pemahaman Bahasa Manusia. Jakarta: Yayasan Obor Indonesia.

Elifia. 2011. Peningkatan Kemampuan Membaca Anak Melalui Permainan Kartu Huruf di TK Amanah Batu Kambing. Jurnal Pesona PAUD Universitas Negeri Padang.

Hariyanto, Agus. 2009. Membuat Anak Anda Cepat Pintar Membaca. Yogyakarta: Diva Press.

Hasan, Maimunah. 2009. Pendidikan Anak Usia Dini. Yogyakarta: Diva Press.

Ismail, Andang. 2006. Education Games. Yogyakarta: Pilar Media.

Izzaty, Rita Eka dkk. 2008. Perkembangan Peserta Didik. Yogyakarta: UNY Press.

Pangastuti, Ratna. 2014. Edutainment PAUD. Yogyakarta: Pustaka Pelajar.

Permendiknas. 2010. Standart Pendidikan Anak Usia Dini. Jakarta: Depdiknas.

Rasyid, Harun dkk. 2009. Asesmen Perkembangan Anak Usia Dini . Yogyakarta: Multi Pressindo.

Sadiman, S. Arif dkk. 2006. Media Pendidikan, Pengertian, Pengembangan dan Pemanfaatannya. Jakarta: PT Raja Grafindo Persada.

Seefeld, Carol dan Wasik, A Barbara. 2008. Pendidikan Anak Usia Dini. (Alih bahasa: Pius Nasar). Jakarta: PT. Indeks.

Sugiyono. 2011. Metode Penelitian Kuantitatif, Kualitatif dan $R \& D$. Bandung : ALFABETA.

Sujiono, Yuliana Nurani, dkk. 2014. Metode Pengembangan Kognitif. Jakarta : Universitas Terbuka.

Suyanto, Slamet. 2005. Dasar-dasar Pendidikan Anak Usia Dini. Yogyakarta: Hikayat Publishing.

Tim PG PAUD Universitas Terbuka. 2015. Analisis Kegiatan Pengembangan Pendidikan Anak Usia Dini. Tangerang Selatan : Universitas Terbuka.

Trisniwati. 2014. Peningkatan Kemampuan Mengenal Huruf melalui Metode Permainan Kartu Huruf pada Kelompok 
B1 TK ABA Ketanggungan Wirobrajan Yogyakarta. Skripsi: Universitas Negeri Yogjakarta.

Waraningsih, Tri Lestari. 2013. Upaya Meningkatkan Kemampuan Mengenal Huruf Menggunakan Media Kartu Kata di TK Sulthoni Ngaglik Sleman. Skripsi : Universitas Negeri Yogyakarta.

Zaman, Badru dkk. 2008. Media dan Sumber belajar TK. Jakarta: Universitas Terbuka. 